\title{
レーダ雨量計データベースと画像処理システム \\ Database for weather radar and image processing system
}

\author{
九州大学工学部 森 山 聡 之 Toshiyuki MORIYAMA \\ 九州大学工学部 平 野 宗 夫 Muneo HIRANO
}

\begin{abstract}
Most of radar hydrogists in Japan have spent a lot of money and time to read and arrange many magnetic tapes recorded by weather radar. A standard format is proposed to share the data file observed by weather radar. We suggest a RAF1 and a RAF2 radar data formats for sequential and random access files. Two systems for the standard file format are also introduced. One is a database system using the RAF2 file format. The other is an image processing system which could treat the data from the database system as image pixels to trace the movements of the rainfall areas.
\end{abstract}

KeyWords : radar, database, image processing

\section{1. 研究の目的}

近年、建設省の手によりレーダ雨量計の全国配備が進められている。これに対応して、河川情報センターにより、レーダの 情報を伝達するシステムも整備されてきている。しかしこの情報は絵情報のため、数值データを必要とする降雨予測や洪水予 測それに土石流や崖崩れの予測をするには十分とは言い難い。そこで数年後には数值データの配信も行うように計画されてい る。一方、研究者レベルで、レーダ雨量データの解析が行われているが、それに使用されるデータは数年に一回程度の豪雨で あり、それ以外の雨量データは整理が大変なため研究者個人レベルではほとんど使用されず、膨大な量の磁気テープを無䭾に 蓄積しているのが現状であり、これらのデータを整備して研究者の使用しやすいデータベースを構築する必要があると思われ る。

本論文では、レーダ雨量計データの標準的なフォ ーマットを提案すると共に、それを実際にブログラ ムして作成したデータベースシステム R a i n M a nkついて解説する。さらに、 R a i n M a nを用 いて検索した雨量データを、2次元の画像として扱 い、画像処理のアルゴリズムを用いて雨量データを 解析するために作成した画像処理システムIMPA CTについても解説する。

\section{2 .標準フォーマットの提案}

レーダ雨量計を用いた各種解析や予測を行うため には、その数值データが不可欠である。現在のとこ ろほとんどの場合、このデータは磁気テープに格納 されているため、高価な磁気テープドライブ装置を 用いて読み取る必要がある。また磁気テープはシー ケンシャル (順次) データのため、磁気テープの終 りのほうにあるデータを読み取るためには、膨大な 量のデータを読み飛ばす必要があり、大型計算機セ ンターのように読みこんだ量に応じて課金されるシ ステムでは、その使用料も馬鹿にならない。このた め、研究者はデータを読み取って整理するのにかな りの時間と精力を費やしているのが現状である。

そこで本論文では、レータ雨量計データの標準化 を提案するものである。各研究者が、それぞれ独自 に読み取った各レーダのデータを標準フォーマット

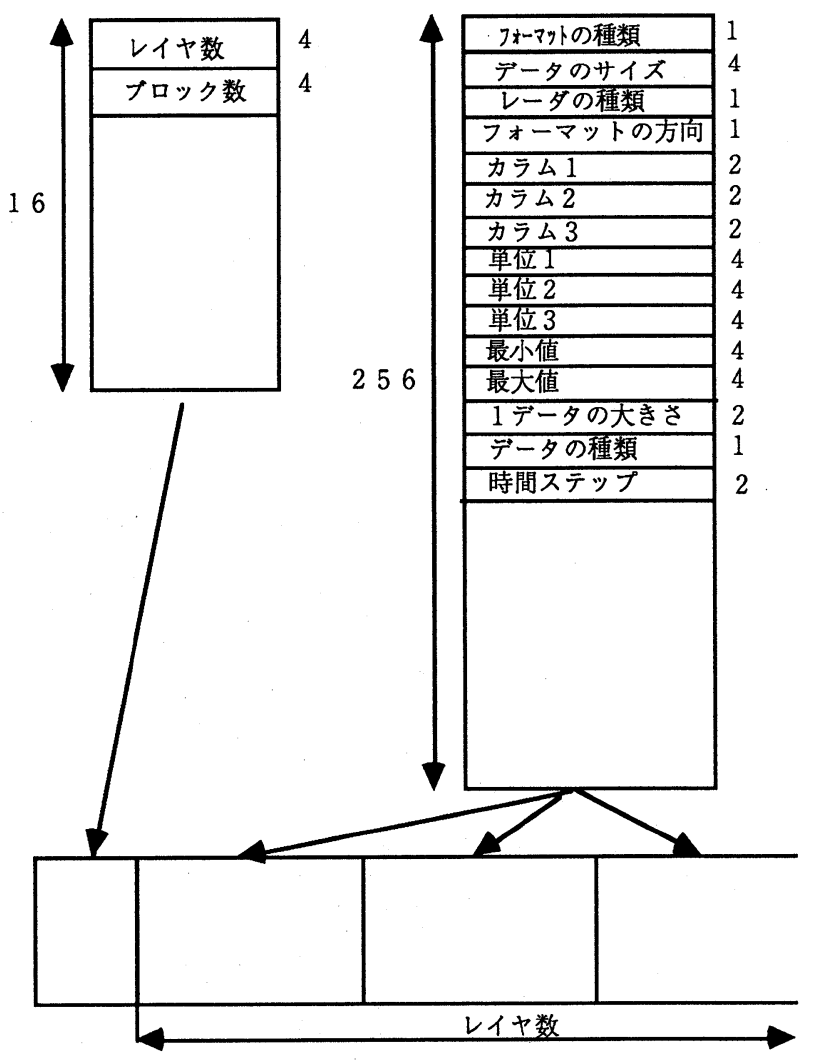

図1 RAF1フォーマットファイルの先頭におけるヘッダ 
に変換することで相互にデータが利用でき、また、同じデータに対して各研究者が作成した気象モデルや予測モデルの比較検 討が出来ることになる。従って、各研究者の交流が活発化し、レーダ雨量計を用いた研究に大きく貢献するものと思われる。

a) RAF1フォーマット

R A F 1 フォーマットは磁気テーブと同様のシーケンシャル（順次形式）フォーマットである。これは大型計算機のように 容易にランダムアクセスファイルを扱えない場合でも対応できるように考虑したものである。このファイルの構造を図 1 及び 図2に示す。

建設省のレーダ雨量データは基本的に極座標形式で、距離に応じて解像度が変る。また建設省の 3 次元レーダは、各仰角毎 にデータが存在する。これらの各データはレイヤ(Layer:層)として分けて扱い同一時刻に観測した各レイヤを1つのブロック としている。各レイヤは物理的特徽量を記録するヘッダーを持っており、更にプロック毎に日時を示すへッダーを持っている。 RAF 1 はこれらブロックの集合であるが、その先頭にはレイヤ数と、プロック数を格納したヘッダーと、各レイヤ毎の観測

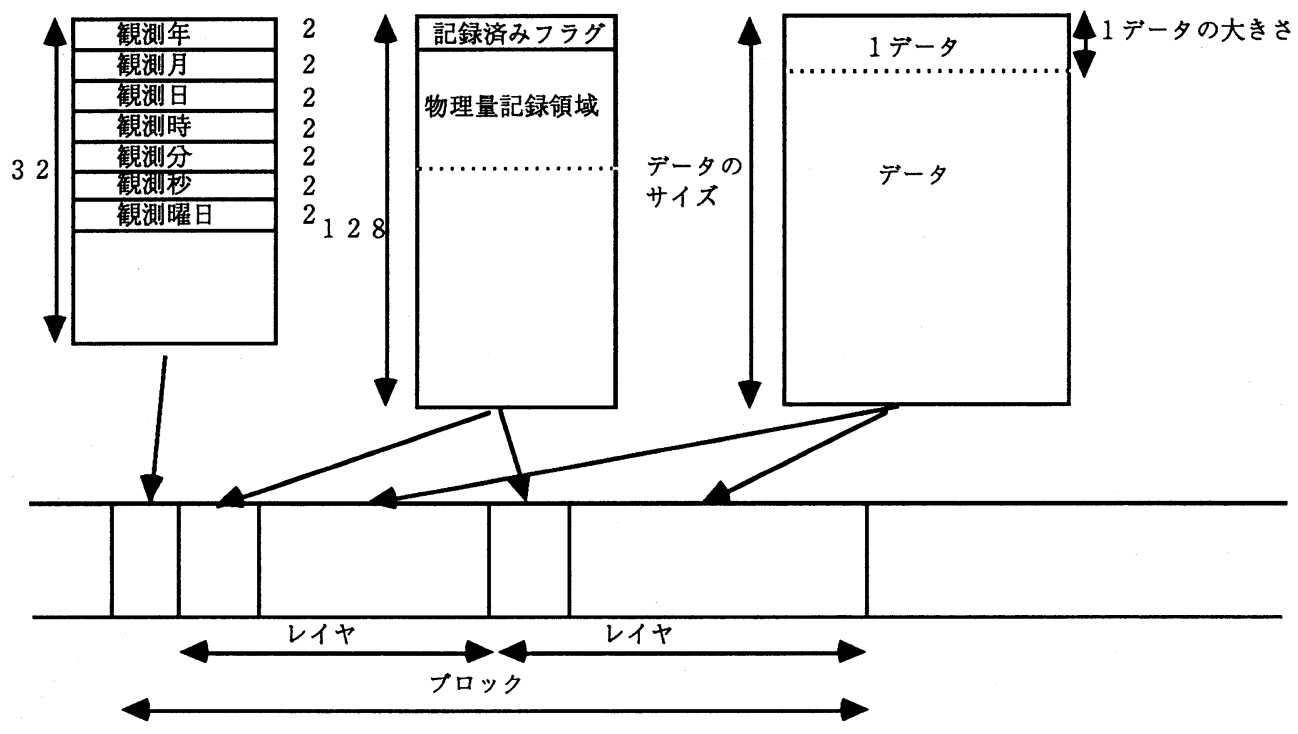

図 2 RAF 1 フォーマットの各レコードブロック

諸元を格納したレイヤ数だけのヘッダーがあり、 各レイヤの処理を行うときの定数となる。

2) RAF 2フォーマット

R A F 2 フォーマットは、パソコンやワーク ステーション或はミニコン等ランダムアクセスフ アイルを容易に扱える機種で、データベースを構 築・管理するためのフォーマットである。データ を格納するファイルは、変換の無䭾を省くため、 R A F 1 フォーマットをそのまま採用し、検索用 の索引キーを各レーダの緒元や物理量・観測日時 等とした検索ファイルを追加したものである。

本論文では、一般的な検索方法である、B i n a r y T r e e (2 分木) を改良したMLー T r e e と呼ばれる索引方法を採用している。 (図 3、4 参照) $\mathrm{ML}-\mathrm{Tr}$ e e は「節」と呼ば れる索引キーのみからなる部分と、レコードへの ポインターを格納する「葉」に分けられるが、そ

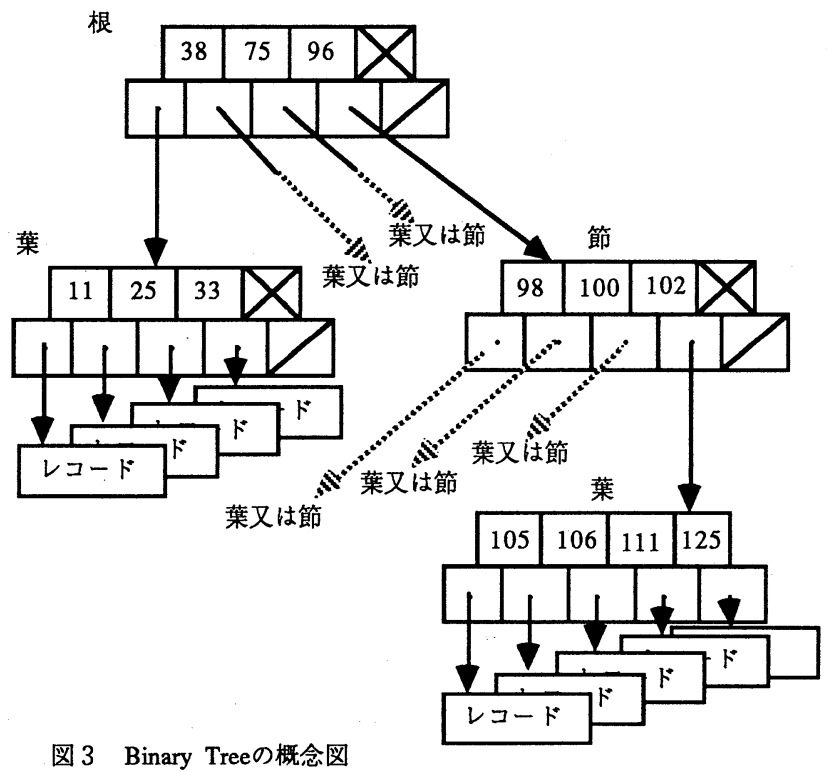




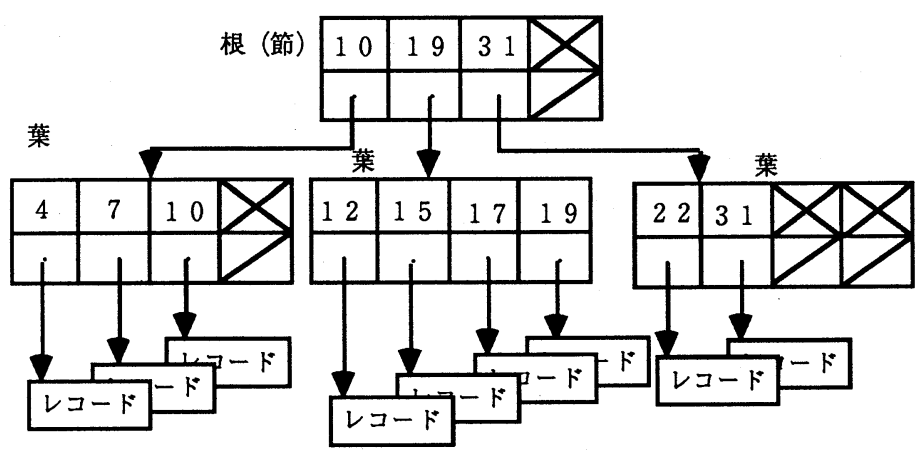

図 $4 \mathrm{ML}$ - T r e e の概念図

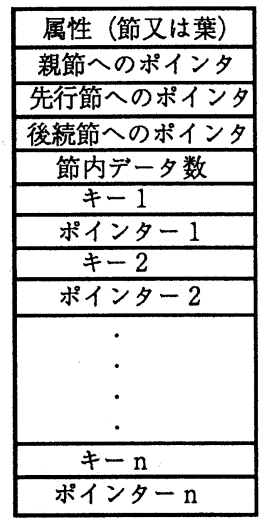

図 $5 \quad \mathrm{ML}$ - T r e e の節構造

の構造は同一である。これを図 5 に示す。

これらのフォーマットは、将来の拡張も見越して現在は使わない部分も予約してある。

3.レータ雨量データ処理システムR a i n M a n

R a i n M a n はレーダ雨量計データを格納し たRAＦ２フォーマットを操作管理するデータベー スシステムであり、現在の機能としては、新規デー タベースの作成・データブロックの追加・各レイヤ の検索表示・データファイル作成などである。現在 収集しているデータは建設省九州北部レーダ・南部 レータ・・沖縄レーダ・九州大学農学部レーダである ので、これらのデータに対応している。検索表示は、 レーダの種類、日時で指定できる。データファイル 作成機能は、必要とするレーダの日時と座標の範囲 を指定すると、希望する時空間の数值データをファ

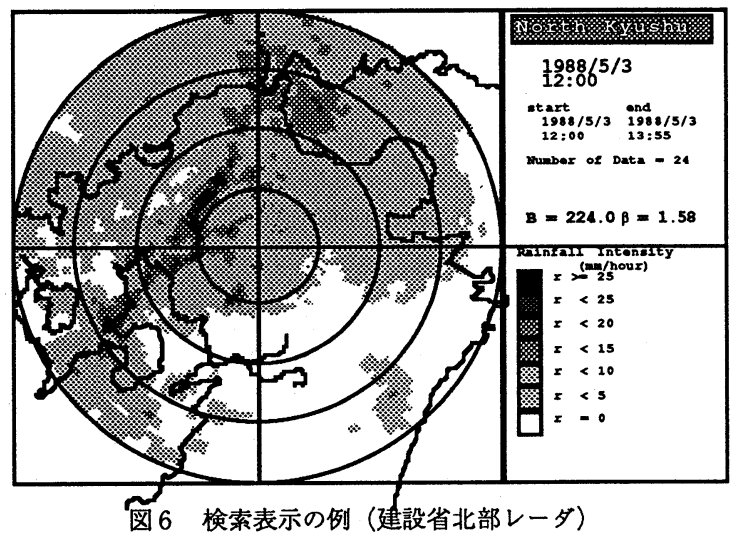
イルに落すことができる。ただし座標系は建設省データの場合、極座標のままである。この際レーダ定数 $\mathrm{B}$ と できる。R a i n M a nを用いて検索表示を行っている例を図 6 に示す。

\section{3 . 画像処理システムIMPAC T}

人間がレーダの画像を見ていると、雨域の移動を目視で簡単に捉えて追跡することができる。ところがこれをコンピュータ に認識させ追跡するのは容易ではない。これは人間が物体を瞬時に（並列的に）認識できるのに対して、現在のコンピュータ は一度に一つの点の情報しか処理できないためである。このため、コンピュータ向きの各種の画像処理法が作成されている。

画像処理システムIMPACT (IMage Processing Analysing Calculating Too 1）は、基本的にはF ORTRANで記述された画像処理サブルーチンパッケージS P I D E Rの機能の一部をパソコンレベ ルのコンピュータで使用するために開発したものである。現在の基本機能は任意の大きさの画像に対し、模擬データ発生・し きい值処理・ヒストグラム処理・領域のラベル付け等であり、補助機能として画像データの圧縮・復元と画像データベースが あり、本格的な画像処理システムを目指している。雨域の追跡用としては、残差逐次近似法（S S D A）を現在組み込み中で ある。この他に微分フィルタリング機能、2 次元 F F T、鳥瞰図表示機能などを組み込み中であり、R a i n M a nで作成し た 2 次元データをデジタル画像と見なして画像処理を行うようになれば、その威力を発揮できるものと期待されている。

\section{5 ハードウエア構成}

使用したハードウエアは図 7 に示すようにMacintoshII（メモリ $8 \mathrm{MB}$ ）に、光磁気デ イスタドライ゚（容量 $650 \mathrm{MB}$ 交換可） 及び1/2亿仿磁気テープドライフ（記録密度 $6250 / 1600$ B P I ）である。MacintoshIIを採用した理由は、

1）優れたマンマシンインターフェースを持ち、各ブログラムでおなじ操作法である。

2) メインメモリーが $8 \mathrm{MB}$ （最人 $1.5 \mathrm{G} \mathrm{B}$ ）まで使用できるため、レーダデータを使用する際MSーDOSバソコンに 
比べ有利である。

3) 安いソフトウエアが揃ってお

ク、プログラム開発環境も整

っている。またプログラムに

関する情報も多いこと。

4) 磁気テープや光ディスクなど

レーダデータを扱うのに必要

な大容量の周辺装置が安価で

入手できる。

などが挙げられる。

6.プログラムの開発

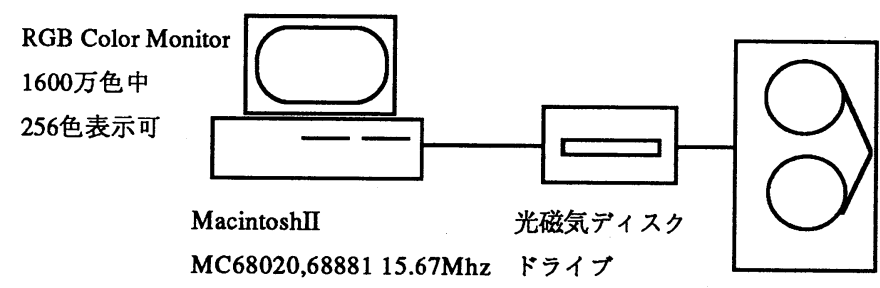

8MB RAM

102MB HD

両面 $650 \mathrm{MB}$ 磁気テープドライブ

図 7 ハードウエア構成
1600/6250BPI

2400Feet(3600feet)

プログラム開発言語には、Macintoshの公式言語であり、初心者でもミスが少なく、容易にプログラムできるPASCALを採 用した。最初は手慣れた Turbo Pascal を用いて、PCー980 1 上で開発したブログラムをMac用の Turbo Pascal に移植した。 I M P A C Tはこの方法で開発している。しかし Turbo Pascal はMac上で使用するにはサポートが不十分であったので、Apple 社純正の開発システムであるM P W（Macintosh Programmer's Workshop）上でTML Pascal II を用いて開発を続行している。R a i n M a n は P C - 98 上の Turbo Pascal からTML Pascal II に移植して開発した。

メニューとウインドウの操作はライブラリProfessional Extender を、それ以外のマンマシンインターフェースはProtoTyper を用いて作成した。

8.おわりに

現在、九州で使用されているレーダ雨量計のデータは R a i n M a n で操作可能なデータベースとすることが出来る。九州 西部レーダも長崎県五島列島に建設中であるが、これへの対応も容易である。またR a i n M a n で検索したデータは、洪水 予測計算や土石流発生予測計算の入力として使用している。

現行バージョンのR a i n M a n は、機能追加の連続で、かなり複雑なプログラムになっており、保守改良が難しい状態に なっている。このためMPW上のオブジェクトクラスライブラリであるMacAPPを使って、全体を書き直し、さらに次の改良 を施す予定である。

1）建設省の円筒座標による原データを直交座標データに変換可能とし、画面表示を高速化すると共に、このデータが I M P A C Tで使用可能とする。

2) 九州の 4 レーダを同時に表示し、かつアメダスやひまわりのデータと比較できるようにする。

3 ) 電話回線やネットワークからでもデータが検索可能で、かつ転送可能にする。

I MP A C T R a i n M a nkよる検索データが使用できるようになれば、その上に降雨域追跡システムを構築する予定 である。

\section{参考文献}

1) 山本米雄・塚本信宏、ML-tree、Information Vol 4、No3 (第2 5 号) (1985)

2) 森山瞈之・平野宗夫、レーダーエコーの画像処理による雨域追跡の試み、土木学会第 39 回年次学術講演会概要集(1984)

3) 森山聡之・国宗真他、画像処理プログラムIM P A C Tについて、第 5 回ソフトウエアコンファレンス(1989)

4) Professional Programer's EXTENDER(マニュアル)、 Invention Software

5) SPIDER USER'S Manual、JSD 共同システム (株)

6) 塩野充著・森俊二監修、BASIC 画像処理プログラム150選、オーム社(1988)

7 ) 安居院猛・中島正之・長尾智春、Turbo Pascal 画像処理の実際、工学社(1988)

8 ) 坂内正夫・大沢裕、画像データベース、昭晃堂(1987) 